\title{
Nonverbal learning disabilities and developmental dyscalculia: Differential diagnosis of two Brazilian children
}

Magda Solange Vanzo Pestun. Universidade Estadual de Londrina

\begin{abstract}
Nonverbal learning disabilities (NVLD), a clinical condition still little reported in Brazil, are characterized by damages in the visual spatial domains, visual motor integration, fine motor skills, math skills and social and emotional difficulties. Developmental Dyscalculia (DD) is a neurodevelopmental disorder that affects basic arithmetic skills acquisition, including storage and recovery of arithmetic facts, calculation fluency and precision and number sense domain. Although both are persistent Math learning disorder/disability, they cause different damages. The objective of this case report is to describe, compare and analyze the neuropsychological profile of two Brazilian children with similar complaints but distinct diagnosis.
\end{abstract}

Keywords: nonverbal learning disabilities; developmental dyscalculia; differential diagnosis.

\section{Resumo}

Transtornos de aprendizagem não verbal e discalculia do desenvolvimento: Diagnóstico diferencial de duas crianças brasileiras. Transtornos de aprendizagem não verbal (TANV), ainda pouco divulgado no Brasil, caracterizam-se por prejuízos nos domínios visuoespacial, integração visuomotora, motricidade fina, habilidades matemáticas e dificuldade social e emocional. Discalculia do Desenvolvimento (DD) é um transtorno do neurodesenvolvimento, com prejuízo na aquisição de habilidades aritméticas básicas, incluindo armazenagem e recuperação de fatos aritméticos, fluência e precisão de cálculo, e domínio do senso numérico. Apesar de ambos serem um transtorno persistente de aprendizagem matemática, envolvem prejuízos diferentes. Este relato de caso tem o objetivo de descrever, comparar e analisar o perfil neuropsicológico de duas crianças brasileiras, com queixa similar, e diagnóstico distinto.

Palavras-chave: transtornos de aprendizagem não verbal; discalculia do desenvolvimento; diagnóstico diferencial.

\section{Resumen}

Trastornos de aprendizaje no verbal y discalculia del desarrollo: Diagnóstico diferencial de dos niños brasileños. Trastornos de aprendizaje no verbal (TANV), aún poco divulgado en Brasil, se caracteriza por perjuicios en los dominios visuoespacial, integración visomotora, motricidad fina, habilidades matemáticas y dificultades social y emocional. Discalculia del Desarrollo (DD) es un trastorno del desarrollo neural, con perjuicio en la adquisición de habilidades aritméticas básicas, incluyendo almacenaje y recuperación de hechos aritméticos, fluidez y precisión de cálculo y dominio del sentido numérico. Pese a que ambos sean trastornos persistentes de aprendizaje de matemáticas, son perjuicios diferentes. Este relato de experiencia tiene el objetivo de describir, comparar y analizar el perfil neuropsicológico de dos niños brasileños, con queja similar, y diagnóstico distinto. Palabras clave: trastorno de aprendizaje verbal; discalculia del desarrollo; diagnóstico diferencial. 
Mastering numbers is as essential in daily routine as mastering letters. However, even nowadays, neuropsychological scientists know more about the dysfunctional cognitive systems present in reading and writing disorders than in disorders in mathematics. Despite receiving increasing attention from researchers over the last five decades, little data on math disorders is reported, especially in Brazil. In a recent search carried out in October 2016 in five databases using the keywords Nonverbal Learning Disability (NVLD), Specific Learning Disability with Impairment in Mathematics (SLDIM) and Developmental Dyscalculia (DD), we have identified only five papers published in Brazil, from 2011 to 2016. Interestingly, four of them deal with DD and only one with NVLD, despite several international studies. In addition to the scarce mentions of NVLD in scientific journals and lack of systematization of the body of knowledge about it, we have not found any studies comparing NVLD and DD. Furthermore, several terminologies are used to designate difficulties with similar performances but with different dysfunctions in mathematics, generating insecurity among professionals who work directly with children with suspected specific learning disabilities with impairment in mathematics.

The Diagnostic and Statistical Manual of Mental Disorders (DSM-5) (American Psychiatric Association [APA], 2014) considers SLDIM, code 315.1 (F81.2), or the alternative term Dyscalculia, as a neurodevelopmental disorder of biological origin that arises in the first years of formal schooling and persists throughout life. It is characterized by difficulties in number sense, reading, writing, and counting impairments, difficulties in memorization, comprehension of arithmetic facts, fluency of calculation, and accuracy of mathematical reasoning, as well as reduced speed of task execution.

Another subtype of specific learning disability is NVLD, not contemplated in the DSM-5 (APA, 2014), but accepted by most international researchers and clinicians as a learning disability. Diagnostic criteria, in particular, have evolved significantly in recent years. In order to verify the strength of criteria for diagnosing NVLD, Mammarella and Cornoldi (2014) analyzed 35 empirical studies, published from January 1980 to February 2011.Their results showed that the most important criteria to distinguish children with NVLD from control children were low visuospatial intelligence with good verbal intelligence, visuoconstructive impairment and fine motor coordination, adequate reading decoding ability, but poor performance in mathematics.
Aditionally, alterations in some language abilities, such as prosody and pragmatics, as well as deficits in abstract reasoning were also observed (Rigau-Ratera, GarciaNonell, \& Artigas-Pallarés, 2004). Further neuropsychological evidence shows deficits in visuospacial working memory required in mental visual image generation tasks (Cornoldi, Rigoni, Tressoldi, \& Vio, 1999). The ability of dealing with novel situations, learning, and executive functions are also affected, compromising concept formation, problem resolution, abstract reasoning, and processing speed. In the domain of social interactions, there are observed difficulties understanding gestures, facial expressions, and voice tone variations, leading to setbacks in social judgement. Rourke (1987) provided the first etiological model for NVLD: the long myelinated fibers of the brain, present in the white matter, are underdeveloped, dysfunctional or injured, which interferes in intermodal integration processes. Most cognitive functions operate in an integrated way, with right hemisphere $(\mathrm{RH})$ and left hemisphere $(\mathrm{LH})$ in cooperation. If one hemisphere is compromised, the functions assigned to it and those resulting from its contribution to the other hemisphere will be dysfunctional. The $\mathrm{RH}$ responds mainly by the processing of visuospatial information, intermodal integration, processing of new information and construction of original schemes. LH responds predominantly to linguistic functions, unimodal processing, and analysis of cognitive processes associated with existing schemas.

The main difference between NVLD and DD is in the contrast between the verbal and nonverbal cognitive impairments of each. In DD, the main difficulty is related to arithmetic and mathematics, and other nonnumerical impairments may or may not present, such as altered executive functions (EF), operational memory, language and visuospatial abilities (Kaufmann et al., 2013). On the other hand, the impairment in mathematics in NVLD occurs in the presence of adequate verbal ability, especially in reading and spelling decoding (Volden, 2013). In addition, in NVLD there are losses in fine motor coordination; in perception, in processing and visuospatial memorization, as well as social skills (Rourke, 1987).

In order to identify individual deficits and potentialities and facilitating a differential diagnosis, the evaluation protocol for children with Specific Learning Disabilities should include tasks of intelligence, verbal and nonverbal memory, attention, executive functions and language, as well as basic reading skills (word 
recognition, fluency, accuracy and textual comprehension), writing (spelling, orthography and spontaneous production of texts) and mathematics (fluency in arithmetic calculations, comprehension and retention of mathematical facts and mathematical reasoning).

Aiming to contribute with procedures more adequate to a differential diagnosis, the present case report describes, compares and analyzes the neuropsychological profile of two Brazilian children, with persistent difficulties in mathematics, one diagnosed with NVLD and the other with a diagnosis of DD.

\section{Method}

Two female children participated in the evaluation. Both were sent for evaluation with a complaint of persistent difficulty in mathematical problem resolution and text interpretation.

C.A., 12 years old, currently a $6^{\text {th }}$ grader of elementary school in a public school, was referred for neuropsychological evaluation in 2013 , at the age of 9 years and 5 months, attending the $3^{\text {rd }}$ grade for the second time. She had received a neurological diagnosis of Attention Deficit Disorder (ADD), in comorbidity with dyscalculia. Since then, she has received treatment with $10 \mathrm{mg} /$ day of Methylphenidate as well as psicopedagogical intervention, with no significant progress in relation to her academic difficulties. Most of her relatives, including mother and father, show learning difficulties and have discontinued their studies. The mother reported that the pregnancy of C.A. occurred normally, and that the birth was at term and natural. She presented typical neuropsychomotor development, uttering the first words at 12 months old and walking with no assistance at 13 months old. She is a very shy child, both at home and in the school environment, who talks little and prefers to play only with her two sisters or alone. She does not make friends easily.

C.G., 10 years old, a fifth grader in a private elementary school, is an only child of separated parents, and lives with her mother and grandfather. In an anamnesis interview, the mother reported that the pregnancy of C.G. was normal, and the birth was at term, with no intercurrences. The neuropsychomotor development occurred in the expected time; she uttered the first words at the age of 18 months old and walked with no assistance at 16 months old. She has always had problems with sleep; she is agitated, wakes up several times during the night and has nocturnal enuresis. C. G. manifests insecurity when she has to make decisions. In school, she has difficulty expressing her ideas, formulating questions and exposing doubts. She is inattentive, slow in executing tasks and disorganized with her materials. In mathematics, she shows difficulty with reasoning and memorizing arithmetic facts.

The instruments used in the evaluation were: Wechsler Intelligence Scale for children (WISC-III) (Figueiredo, 2002); Rey Auditory Verbal Learning Test (RAVLT) (Malloy-Diniz, Lasmar, Gazinelli, Fuentes, \& Salgado (2010); Rey Complex Figure Test, (Oliveira \& Rigoni, 2010); Bender`s test (Sisto, Noronha, \& Santos, 2006); Stroop test (Ducan, 2006); Wisconsin Card Sorting Test (WCST) (Cunha et al., 2005); Brazilian Children's Test of Pseudoword Repetition (BCPR) (Santos \& Bueno, 2003); Phonemic targeting task (Capovilla., Montiel, \& Capovilla, 2007); Educational Achievement Test (EAT) (Stein, 1994); Arithmetic test (Capovilla et al., 2007), as well as text for reading and interpretation (Alliende, Condemarin, Chadwick, \& Milicic, 1994).

The neuropsychological evaluation was initiated with an anamnesis interview with the mother, in which she signed the Free Informed Consent Form (FICF), followed by a rapport session with the child and eight sessions of neuropsychological tests. Finally, feedback was given to the children's parents, as well as to their teachers.

\section{Results}

In the neuropsychological evaluation, C.A. presented average intellectual performance, with significant discrepancy between the verbal and nonverbal area (WISC-III). She showed above-average performance in the sub-vocabulary, similarities, digits and figure completion subtests, while the first three subsets relate to the verbal area. Below average performance was detected in the information, comprehension, arithmetic, object assembly, symbol search, arranging figures and looking for symbols subtests (the last four being related to the execution area).She showed good longterm verbal memory skills (RAVLT) and good phonological working memory (BCPR); selective attention, sustained and inhibitory control (Stroop test), phonological awareness (task of phonemic manipulation), as well as adequate reading of words and orthography (Table 1).

However, she showed a great deal of difficulty in visuospatial and visuomotor tasks, verified through 
Nonverbal learning disabilities and developmental dyscalculia: Differential diagnosis of two Brazilian children

Table 1. C.A. and C.G. Performances in Neuropsychological Tests

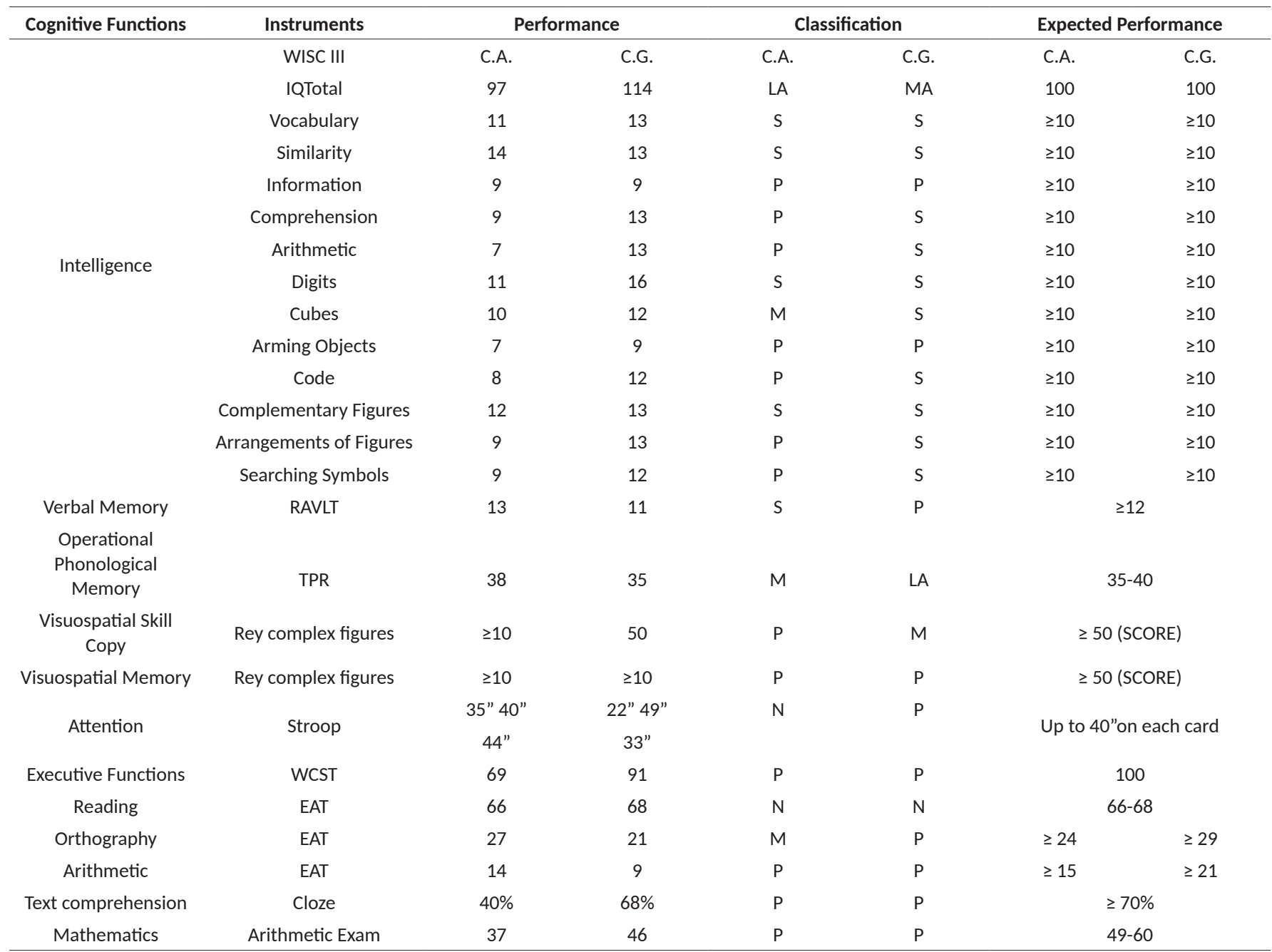

Note. WISC-III (normative data - weighted points); RAVLT (normative data - gross points); BCPR (normative data - gross points); Rey Complex Figures (normative data - percentile); Stroop Test (time of up to 45 seconds on each card); WCST (normative data); EAT (normative data for the $3^{\text {rd }}$ grade - C.A and $5^{\text {th }}$ grade - C.G); Arithmetic Exam(normative data). $S$ (superior performance); M (medium performance); P (poor performance); N (normal performance); LA (lower average performance); SA (superior average performance).

the Rey complex figure copy test and the Bender test (Figure 1).

In Rey complex figures, she reversed the drawings in the two moments (copy and memory), showing difficulty in the spatial location of the elements, in the overall perception of the figure, in visuospatial integration, as well a fine motor impairment. Due to the degree of difficulty shown by C.A. in this ability, the Bender test was applied, and the results of 65 (percentile) and 75 (quartile) confirmed visuomotor immaturity. In addition, she presented a deficit in nonverbal abstract reasoning, verified through the WCST test, where she filled out only three of six categories in 128 essays, and in the Cloze activity for text interpretation, where she only scored $40 \%$ of the maximum performance, demonstrating difficulty with inference and figure of speech comprehension. In relation to numbers, she showed difficulty in the three measures employed: the WISC-III arithmetic subtest, the EAT arithmetic subtest and the arithmetic test. She showed easiness in remembering arithmetic facts, but committed borrowing errors and conceptual losses.

In the neuropsychological evaluation, C.G. showed superior intellectual performance for both verbal and execution areas. She showed below-average performance only in two subtests: object assembly, 


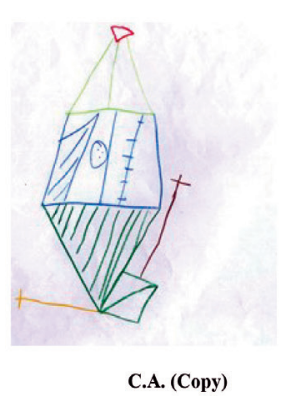

C.A. (Copy)
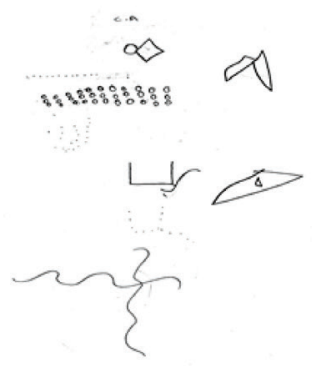

C.A. (Bender Test)

Figure 1. Rey Complex Figures

which measures the ability of visual information synthesis and analysis, and long-term memory, which measures accumulated knowledge throughout life. She also had good performance in a visuoconstructive task (Rey Complex Figure Copy), in word reading and in phonological operational memory. She showed difficulties in visuospatial memory (memory recall of the Rey complex figure copy), in sustained attention (Stroop test), executive functions (WCST), long-term verbal memory (RAVLT), orthography and arithmetic (EAT), and in written operations of the arithmetic test. She showed greater difficulty in solving elementary calculations and in memory related to arithmetical facts. For instance, she did not solve operations of multiplication, division, addition and subtraction with multiple digits, despite attending the fifth grade and showing higher average intellectual potential, a characteristic of DD (DSM-5, 2014).

\section{Discussion}

In this case report, we present two children with similar complaints: difficulties in mathematics and text interpretation. We analyzed their performances in neuropsychological tests, leading to two different diagnoses, one related to NVLD and the other to DD.
What differentiated NVLD from DD were the significant deficits in visuospatial and motor abilities, nonverbal abstract reasoning, comprehension and resolution of mathematical problems (tasks), text interpretation, social cognition, visuospatial operational memory, and speed of though; all manifested by C.A. Difficulties in attentional and linguistic abilities, phonological operational memory, executive functions and numerical cognition, on the other hand, were present in C. G. According to Mammarela and Cornoldi (2014), for the diagnosis of NVLD, the child must meet at least three of the four criteria described below. Only C.A. fulfilled these requirements.

\section{Criterion 1 - Verbal Intelligence Better than Visuospatial Intelligence}

While C.G. showed superior balance in both areas, C.A. showed a verbal IQ superior to the executive IQ. This accentuated discrepancy between verbal IQ and executive IQ can be due to alterations in the functioning of white matter, predominant in the $\mathrm{RH}$, and involved mainly in visuospatial abilities (Rourke, 1987). In addition, according to Drummond, Ahmad and Rourke (2005), the child should show high performance in at least two of three WISC-III verbal subtests - vocabulary, similarities and information (verbal intelligence) - and 
poor performance in at least two of three subtests of the nonverbal area - block design, object assembly and code (visuospatial intelligence). Both children showed above average performance in similarities and vocabulary subtests, and below-average performance in arming objects. C.A., however, showed worse performance in two other execution subtests (block design and code), compared to C.G. (Table 1).

\section{Criterion 2 - Visuoconstructive and Praxis Impairments}

Only C.A. showed visuoconstructive impairments in all applied tests (Rey complex figure copy, Bender test and in the WISC-III object assembly subtest). As it can be observed in Figure 1, the severity of C.A.'s impairment is striking, both visuospatial and in praxis. Such finding is supported by national and international literature, which consider this type of difficulty to be the central deficit of the NVLD (Mammarella \& Cornoldi, 2014; Rigau-Ratera et al., 2004; Wajnsztejn, Bianco, \& Barbosa, 2016). There have been some interesting explanations for this observed difficulty. Wajnsztejn et al. (2016) found an interhemispheric asymmetry in 14 Brazilian children and adolescents with a NVLD diagnosis. The authors propose the hypothesis that the difficulties in visuoconstructive tasks and in arithmetic could be due to this asymmetry of the RH. Cornoldi et al. (1999) attributed the visuospatial difficulties in children with NVLD to the inefficiency in visuospatial working memory (VSWM) requiring generation of mental images. That is a possible explanation for the deficits shown by C.A.

\section{Criterion 3 - Poor Performance in Mathematics with Good Reading Decoding Ability}

Both children showed a positive reading decoding ability, but C.A. showed better orthography compared to C.G., despite C.A.'s difficulties with inferential reasoning and abstract ideas, a characteristic of NVLD. As for mathematics, both C.A. and C.G. showed inferior performance in EAT arithmetic and in the arithmetic test. Arithmetic difficulties are often associated with NVLD and DD, however, the errors presented in either of the conditions are different. For example, children with NVLD usually have no problem remembering arithmetic facts, but they commit visuospatial errors, such as confusing columns in the writing of calculations or procedures (e.g., borrowing and raising), and poor reasoning and problem solving skills. That is the case of C.A, who knows the oral and written symbology of numbers, as she can write them down when prompted, but does not understand the functions of the digits and how to distribute them in space. Graná, Hofer and Semenza (2006) verified the same pattern of deficits in a patient who had suffered damage to the $\mathrm{RH}$ and showed mistakes in multiplication procedures, despite the intact ability to recall arithmetic facts. Said authors hypothesized that this was caused by a disturbance of spatial working memory. Consequently, while knowing what, when and how to carry out the various steps of the procedures, the patient does not know where. Thus, what he may lack is a spatial schema of multiplication. Veneri, Cornoldi and Garuti (2003) compared NVLD and controls in arithmetical calculations, finding the disabled group's difficulties more severe in written calculation. They hypothesized that children with NVLD do not have a generalized difficulty with calculation per se; their problems emerge instead when dealing with specific processes, including VSWM, which governs calculation. Mammarella, Lucangeli and Cornoldi (2010) confirmed this hypothesis of impaired performance in written calculation, and in number ordering tasks. In DD, there are more errors in the calculation itself and in memory for arithmetic facts (Osmon, Smerz, Braun, \& Plambeck, 2006). It is frequently pointed that a hypofunctioning of the right parietal lobe (a region related to numerical and quantity senses) would explain both DD as well as the attentional deficit (Furman \& Rubinsten, 2012), which is the case of C.G.

\section{Criterion 4 - Deficits in Socioemotional Skills}

Shyness, interaction and communication deficits were reported both by C.A.'s mother and her teacher. Similar results have been found by Wajnsztejn et al. (2016).

This case study sought to contribute towards the characterization of NVLD, as well as to highlight the importance of a differential diagnosis. However, further research with a larger sample of children and including other learning disorders, such as dyscalculia in comorbidity with dyslexia, as well as other comorbidities (e.g., anxiety, depression, phobias), is necessary in order to better comprehend the differences in the functional deficits presented by children with NVLD and DD.

\section{References}

American Psychiatric Association (2014). Manual diagnóstico e estatístico de transtornos mentais: DSM-5. 5. Porto Alegre: Artmed.

Alliende, F., Condemarin, M., Chadwick, M., \& Milicic, N. (1994). Compreensão da leitura I. Campinas: Psy II. 
Capovilla, A. G. S., Montiel, J. M., \& Capovilla, F. C. (2007). Prova de aritmética. In A. G. S. Capovilla \& F. C. Capovilla (Orgs.), Avaliação Neuropsicológica (pp. 54-60). São Paulo: Memnon.

Cornoldi, C., Rigoni, F., Tressoldi, P. E., \& Vio, C. (1999). Imagery deficits in nonverbal learning disabilities. Journal of Learning Disabilities, 32, 48-57. doi: 10.1177/002221949903200105

Cunha, J. A., Trentini, C. M., Argimon, I. L., Oliveira, M. S., Werlang, B. G., \& Prieb, R. G. (2005). Adaptação e padronização brasileira do Teste Wisconsin de classificação de cartas - WCST. São Paulo: Casa do Psicólogo.

Drummond, C. R., Ahmad, S. A., \& Rourke, B. P. (2005). Rules for the classifications of younger children with nonverbal learning disabilities and basic phonological processing disabilities. Archives of Clinical Neuropsychology, 20, 171-182. doi: 10.1016/j. acn.2004.05.001

Duncan, M. T. (2006). Obtenção de dados normativos para desempenho no teste de Stroop num grupo de estudantes do ensino fundamental em Niterói. Jornal Brasileiro de Psiquiatria, 55(1), 42-48. doi: 10.1590/S0047-20852006000100006

Figueiredo, V. L. M. (2002). Adaptação e padronização brasileira da escala deinteligência Wechsler para crianças, terceira edição WISC-III. São Paulo: Casa do Psicólogo.

Furman, T., \& Rubinsten, O. (2012). Symbolic and non symbolic numerical representation in adults with and without developmental dyscalculia. Behavioral and Brain Functions, 8, 55. doi: 10.1186/1744-9081-8-55

Graná, A., Hofer, R., \& Semenza, C. (2006). Acalculia from a right hemisphere lesion Dealing with "where" in multiplication procedures. Neuropsychologia, 44, 2972-2986. doi: 10.1016/j. neuropsychologia.2006.06.027

Kaufmann, L., Mazzocco, M. M., Dowker, A., von Aster, M., Göbel, S. M., Grabner, R. H., ... Nuerk, H. C. (2013). Dyscalculia from a developmental and differential perspective. Frontiers in Psychology, 4, 516. doi: $10.3389 /$ fpsyg.2013.00516

Malloy-Diniz, L. F., Fuentes, D., Abrantes, S. S. C., Lasmar, V. A. P., \& Salgado, J. V. (2010). Teste de aprendizagem auditivo-verbal de Rey (RAVLT). In L. F. Malloy-Diniz, D. Fuentes, P. Mattos, \& N. Abreu (Eds.), Avaliação Neuropsicológica (pp. 335-343). Porto Alegre: Artmed.

Mammarella, I. C., \& Cornoldi, C. (2014). An analysis of the criteria used to diagnose children with Nonverbal Learning
Disability (NLD). Child Neuropsychology, 20(3), 255-280. doi: 10.1080/09297449.2013.796920

Mammarella, I. C., Lucangeli, D., \& Cornoldi, C. (2010). Spatial working memory and arithmetic déficits in children with nonverbal learning disabilities (NLD). Journal of Learning Disabilities, 43, 455-468. doi: 10.1177/0022219409355482

Oliveira, M. S., \& Rigoni, M. S. (2010). Figuras complexas de Rey: teste de cópia e de reprodução de memória de figuras geométricas complexas. São Paulo: Casa do Psicólogo.

Osmon, D. C., Smerz, J. M., Braun, M. M., \& Plambeck, E. (2006). Processing abilities associated with math skills in adult learning disability. Journal of Clinical and Experimental Neuropsychology, 28 , 84-95. doi: 10.1080/13803390490918129

Rigau-Ratera, E., Garcia-Nonell, C., \& Artigas-Pallarés, J. (2004). Características del transtorno de aprendizaje no verbal. Revista de Neurología, 38(1), S33-S38. Retrieved from https://www.neurologia. com/articulo/2004056/esp

Rourke, B. P. (1987). The syndrome of nonverbal learning disabilities: the final common pathway of White-matter disease/ dysfunction?. The Clinical Neuropsychologist, 1, 209-234. doi 10.1080/13854048708520056

Santos, F. H., \& Bueno, O. F. A. (2003). Validation of the Brazilian Children's Test of Pseudoword Repetition in Portuguese speakers aged 4 to 10 years. Brazilian Journal of Medical and Bi Research, 36(11), 1533-1547. doi: 10.1590/S0100-879X2003001100012

Sisto, F. F., Noronha, A. P. P., \& Santos, A. A. A. (2006). Teste GestálticoVicomotor de Bender: Sistema de pontuação gradual (B-SPG). São Paulo: Vetor.

Stein, L. M. (1994). TDE: Teste de desempenho escolar: manual. São Paulo: Casa do Psicólogo.

Venneri, A., Cornoldi, C., \& Garuti, M. (2003). Arithmetic difficulties in children with visuospatial learning disabilities (VLD). Child Neuropsychology, 9, 175-183. doi: 10.1076/chin.9.3.175.16454

Volden, J. (2013). Nonverbal learning disability. In O. Dulac, M. Lassonde, \& H. B. Sarnat (Eds.), Handbook of clinical neurology (pp. 245-249). doi: 10.1016/B978-0-444-52891-9.00026-9

Wajnsztejn, A. B. C., Bianco, B., \& Barbosa, C. P. (2016). Prevalence of inter-hemispheric asymetry in children and adolescents with interdisciplinary diagnosis of non-verbal learning disorder. Einstein, 14(4), 494-500. doi: 10.1590/s1679-45082016ao3722

Magda Solange Vanzo Pestun, Doutora em Ciências Médicas, área de Ciências Biomédicas, pela Faculdade de Ciências Médicas da Universidade Estadual de Campinas (FCM-UNICAMP), é Professora Associado C na Universidade Estadual de Londrina (UEL). Endereço para correspondência: Rua João Huss, 115, apt.1504, Londrina PR. CEP: 86.050-490. Telefones: (43)3326-6235; (43)99993-6235. E-mails: pestun@sercomtel.com.br; pestun@uel.br 